しその後流に四すい形（然料の多いときはりング狀） のスタビライザーを括き，その中に点火せんを拓く 型式. Wまの所もつともよいが燃料分布は実蔹的にき める.

排氝口か埶くなるための諸閵題は大体解決した。ガ ス溶接より霞氝溶接の方がよい，点火せんはどうし ても長くもたない，再熱の效果を十分発揮するには可 変排氝口にしなければならない。[岡䗁，卓郎]

\section{[103]噴油量の少レときにす辰好な 霧化を得られるハッズル}

[S.A.E. Journal, Vol. 58, No. $2(1950-2)$ p. 22 〜25] ガスタービンに括いて良好な然燒狀態を得 るには然粼をこまかい雺狀にして常に供給しなければ ならないが第1圖に示したような普通用いられる單純

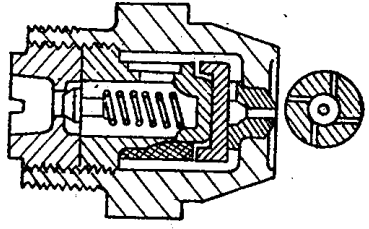

第 1 図

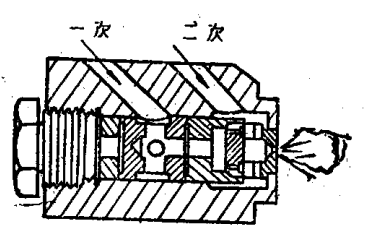

第、2 図
ノッズルは，低負荷に晾ける擎化が良好になるように 設計すると最大負荷のときの噴射王力が極端に高くな り，従つてこのときの最大玨力を㬰用上可能な值に如 さえると，タービンの低負荷運転が制限される結果に なつている．この点を解決するために第 2 圆の上うな 䄍合ノッズルが考案された。
これは僬鿓荷の時は一次喛孔のみより燃料が供給さ れ，高船荷のときには二次噴孔からも，頶射されて， 生力の上昇防ぐようにしたすので，これを用うると 最大負荷のときの噴射圧力を $500 \mathrm{lb} /[]^{\prime \prime}$ にして,から

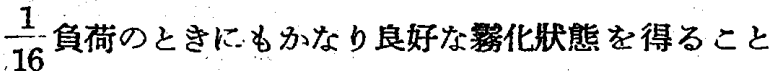
ができるとしている，さらに噴孔の面積が圧力によつ。 て変化するような構造のものは性能は良好であるが; 機械的な㰆造がさつかしく，まだ実用にはならぬとし ている.な叔ららなノッズルを多数使用するとき は分配器が必要で岁る。[本尾收]

\section{[104〕アンチハックエンギン}

[S.A.E. Journal, Vol. 58, No. 2 (1950-2) p. 49* 〜53] ガンリン発動機に括けるノックを防ぐには， オクタン價の高い然料を用らることは常識となつてい るが，筆者はノックを起し雖い発動機を用いて，低い オクタン價の然料を用いて，高い玨樎比を探用し，效; 率の高い発動機を作る見达みが岕るとして，このよう な発動機の具借すべき條件は，1．現在の高溫の排氝 弁をなくすること．2．弁の强制駆動．3. 製作費が 特に高くならないこと.であるとし，現在まで 1，2， の條件を満足するすらとしては摺動弁発動機，『スピ ン発動機を安げ，その得失を述べている，最後に上の

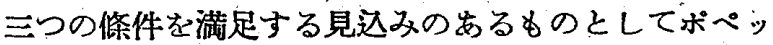
卜弁を1筬だけ有し，これで吸排氝を行らいわゆる單 弁発動機を炭げ，その起源，発達の過程，種々の変型 について述べ, 最もよいと思われる形式を示してい る. [本尾”收]

\title{
10.自動車および自動車機關
}

\section{[105]空冷小形ディーゼル機關}

[Automotive Industries $\ddot{n}$, Automotive Industries, Vol. 101, No. 7, October 1, 1949, p. 2, 写溑 1, 萑 1】 小形車両用としての茎冷小形デイーゼルは非常 に興味をるものと思われる。ここに紹介するすのはコ ンチネンタル自動車会社が最近発表したもので 2 シ ンダと 4 シリンダのものがある。前者は通常馬力に て, $1829 \mathrm{rev} / \mathrm{mn}, 975$ Bhp. 後者心 $24000 \mathrm{rev} / \mathrm{mn}$, $25 ` 14$ Bhp. いずれ女対问ピストン型，4サイクル， 王綰点火，ボッシュの燃料ポンプを探用し，然費は 2 シリンダで 0 495 lb/Bhp/hr, 4 シリンダで 0`47 lb/Bhp

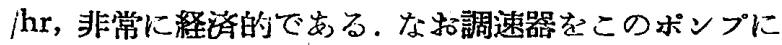
含んでいる.クランクケース，シリンダへッド，ピス トン，オイルパン等はアルミ合金を使用して重量を軽 減し，4 本のビストンリングでガス洩れを防いでいる

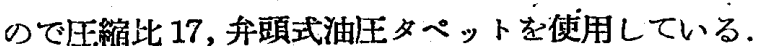
完備したオイルフィルタおよび燃料瀘過器を持ち，始 動は手動または想動。潤滑は强制潤滑. 軸流冷却ファ ンを駆動し，その空気流がシリンダカバーによつて導 かれるので冷却は完全で㐫る．最初海軍よりの命令で

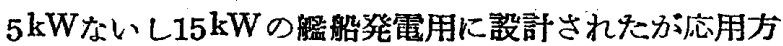

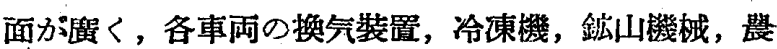
羓用ポンプ等に使用の道が開けているが私は小形車両 用駆動裝置としての將來に注目する。[琴田 栄头]

\section{〔106]ピストンアッセンブリ}

[J. L. Hepworth, Automobile Engineer, 194912, p. 528-534] ピストン破壤の種々の場合につ いて，その原因と対策とを論じたのち，ピストンアッ

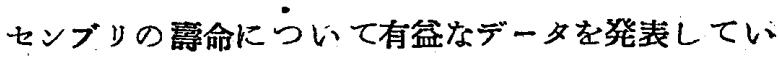




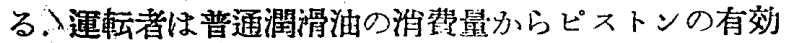
壽命起制定するが，この場合潤滑油を搔き取り過ぎる リングを備えたェンジンは却つて長期間では経済的で はない沖えんを說明している，次にピストン，同リン グ，同ビンなどの摩耗割命の試䍉結果を述べ，トップ リングが最も脆弱点で岁ると結馀している。そこでリ ングの材質を变えて実用訊駼を行つた結果，トップリ シグとしてはクロムめつきしたものが最良で岕ると考 えられた。最後にこれらの経鮙をもととして，ピス トンを設計するときの参考事項が浦べて岁る，現在イ

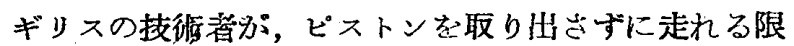
度の目標を 100000 マイルとしていることを思うと きわれわれはさらに研究しなくてはならぬことを感

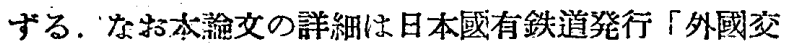
通調查資料（技街編）」5月号に揭踐の予定で出る。

[土伎 奏光]

\section{[107] 米國 1949～1950 年乘用車 鈛關の要目性能}

[The American Automobile., 1950-2, Vol 27, No. 2, p. 128-130] 米國の 1949 1950 年型乘 用車 51 種にわたつて，車体の主要諸元；機関の要目； オイル, ガソリン, 冷却柔統の容壆; 氠化器, 電氝系 統, 䈉電池, 变速機, クラッチ, 後車軸, ブレーキの 製造社名，型式，大きさ等が一覧表にして岁る。.

ここには機関の要目と，それを基化計算した行程內 径比 $r$, 最高平均ピストン速度 $v_{m}$, 最高平均有效忹 $p_{m e}$ ，最高馬力に対するトルク $T$, リッター当り䲱力 $N_{l}$ とを併せて一覧琵にした。 な法評算は次式によつ た.

$$
\begin{aligned}
& D=\text { シリンダ內径 } \mathrm{cm}, \quad L=\text { 行程 } \mathrm{cm} \text {, } \\
& V=\text { 排分容積 } l, N_{m}=\text { 最高馬力 } \mathbb{P} \text {, } \\
& n=\text { 最高馬力に対する回転数 } \mathrm{rev} / \mathrm{mn} \text {. } \\
& r=\frac{L}{D} \\
& v_{m}=\frac{L n}{3000} \mathrm{~m} / \mathrm{s} \\
& p_{m e}=\frac{900 N_{m}}{V n} \mathrm{~kg} / \mathrm{cm}^{2} \\
& T=71620 \frac{N_{m}}{n} \cdot \mathrm{kg}-\mathrm{m} \\
& N_{l}=\frac{N_{n n}}{V} \cdot \mathbb{F} / l
\end{aligned}
$$

[平非 䨘明]

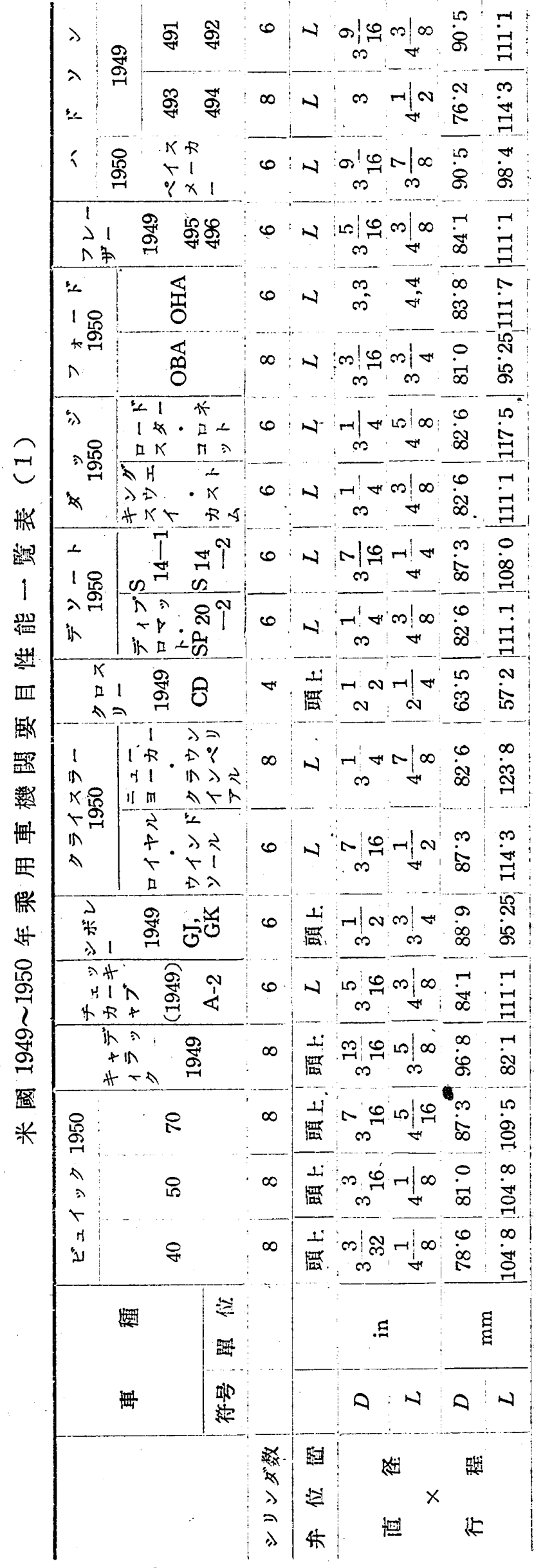

